"Impact of non-interest income and revenue concentration on bank risk in South Asia"

$\begin{array}{ll} & \text { Ahmed Imran Hunjra } \text { https://orcid.org/0000-0002-7272-3684 } \\ & \text { Qasim Zureigat (D https://orcid.org/0000-0002-6864-8650 } \\ & \text { Tahar Tayachi (Dttps://orcid.org/0000-0002-1391-7665 } \\ \text { AUTHORS } & \text { Rashid Mehmood (D https://orcid.org/0000-0001-8520-6523 }\end{array}$

ARTICLE INFO

Ahmed Imran Hunjra, Qasim Zureigat, Tahar Tayachi and Rashid Mehmood

\begin{tabular}{ll} 
ARTICLE INFO & $\begin{array}{l}\text { South Asia. Banks and Bank Systems, 15(4), 15-25. } \\
\text { doi:10.21511/lbs.15(4).2020.02 }\end{array}$ \\
\hline DOI & http://dx.doi.org/10.21511/bbs.15(4).2020.02 \\
\hline RELEASED ON & Friday, 30 October 2020 \\
\hline RECEIVED ON & Monday, 13 April 2020 \\
\hline ACCEPTED ON & Tuesday, 13 October 2020 \\
\hline LICENSE & $\begin{array}{l}(\text { (c) }) \text { EY } \\
\text { This work is licensed under a Creative Commons Attribution } 4.0 \text { International }\end{array}$ \\
\hline JOURNAL & License \\
\hline ISSN PRINT & "Banks and Bank Systems" \\
\hline ISSN ONLINE & $1816-7403$ \\
\hline PUBLISHER & $1991-7074$ \\
\hline FOUNDER & LLC “Consulting Publishing Company "Business Perspectives" \\
\hline
\end{tabular}

NUMBER OF REFERENCES

63

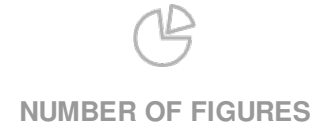

0

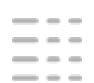

NUMBER OF TABLES

5

(C) The author(s) 2021. This publication is an open access article. 


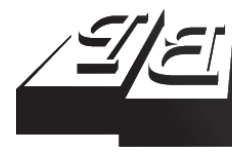

\section{BUSINESS PERSPECTIVES}

()

LLC "CPC "Business Perspectives"

Hryhorii Skovoroda lane, 10, Sumy, 40022, Ukraine

www.businessperspectives.org
Received on: $13^{\text {th }}$ of April, 2020 Accepted on: $13^{\text {th }}$ of October, 2020 Published on: $30^{\text {th }}$ of October, 2020

(C) Ahmed Imran Hunjra, Qasim Zureigat, Tahar Tayachi, Rashid Mehmood, 2020

Ahmed Imran Hunjra, PostDoc \& Ph.D., Assistant Professor, University Institute of Management SciencesPMAS-Arid Agriculture University Rawalpindi, Pakistan. (Corresponding author)

Qasim Zureigat, Ph.D., Professor, School of Business, Sulaiman AlRajhi University, Saudi Arabia.

Tahar Tayachi, Ph.D., Assistant Professor, Chair of Finance Department, Effat College of Business Effat University, Jeddah, Saudi Arabia; Finance Department, FSEG Mahdia, Université de Monastir, Mahdia, Tunisia.

Rashid Mehmood, Ph.D., Assistant Professor, Department of Economics and Business Administration, Division of Arts and Social Sciences, University of Education, Lahore, Pakistan.
This is an Open Access article, distributed under the terms of the Creative Commons Attribution 4.0 International license, which permits unrestricted re-use, distribution, and reproduction in any medium, provided the original work is properly cited.

Conflict of interest statement: Author(s) reported no conflict of interest

Ahmed Imran Hunjra (Pakistan), Qasim Zureigat (Saudi Arabia), Tahar Tayachi (Saudi Arabia), Rashid Mehmood (Pakistan)

\title{
IMPACT OF NON-INTEREST INCOME AND REVENUE CONCENTRATION ON BANK RISK IN SOUTH ASIA
}

\begin{abstract}
Banks not only rely on the traditional way of generating income, they also opt for non-interest income (NII) to survive in a competitive environment. Banks in South Asia are diversifying their income from interest to non-interest sources in order to reduce risk and generate high returns. This study examines the impact of non-interest income (NII) and revenue concentration on banks' risk in South Asian countries such as Pakistan, Sri Lanka, India and Bangladesh. Panel data for eighty-five banks from 2009 to 2018 is used. Generalized Method of Moments (GMM) is employed to analyze the data. The study finds that non-interest source income and revenue concentration significantly affect bank risk in the overall analysis. The study finds different results depending on the regulations and application of the regulatory system in each country. Non-interest income reveals a significant impact on bank risk for Pakistan, India and Bangladesh, but insignificant for Sri Lanka. Revenue concentration has a significant effect on bank risk in Pakistan and India, however, it does not affect bank risk in Sri Lanka and Bangladesh. This study recommends that bank managers focus on different sources of revenue generation in order to minimize their level of risk through a diversification strategy to enhance efficiency. This study contributes to the banking sector literature of South Asian markets.
\end{abstract}

Keywords

JEL Classification

\section{INTRODUCTION}

The banking industry is facing challenges of new banking environment due to increase in competition, forcing it to adopt the diversification strategy to play a new role in the financial sector (GutierrezLopez \& Abad-Gonzalez, 2020). Such changes lead to an increase in the non-interest income (NII) of banks. Competition in the banks leads to decline in interest revenue, which ultimately forces the banks to generate non-traditional income source. Therefore, banks have experienced a big change in their income structure. Banks' non-interest income arises from non-traditional banking activities, which include income from fee, general services, commission, etc. (Yao et al., 2018). As banks are progressively operating to raise productivity, one approach is to enhance earnings based on non-conventional sources. In the recent past, the 2007-2008 crises severely affected the investment-oriented banks. Non-interest income is normally unpredictable than interest income (DeYoung \& Ronald, 2001). It is understood that bank risk reduces because of diversification of various income sources, and banks are able to absorb variation in the interest income (Demsetz \& Strahan, 1997). Furthermore, an increase in non-traditional income can help banks in reducing volatility in profits since it does not depend on the traditional activities of 
banks. There is a tendency that banks can enhance their profit due to non-interest income (Hidayat et al., 2012).

Over the span of their operations, banks continuously confront various kinds of risks that may negatively affect their businesses. All banks have their own risk management divisions to screen, oversee, and measure the risks. Global Financial Crisis (GFC) 2007-2008 has also put emphasis on the importance of bank's income diversification and risk. DeYoung and Torna (2013) explain that GFC is liable for an increasing trend of non-traditional business activities in banks. Brunnermeier et al. (2012) report that a bank with higher non-traditional income exhibits a higher level of systematic risk.

Therefore, non-interest income and revenue concentration have raised greater attention in the banking sector. This motivates researchers to evaluate the influence of non-interest income and revenue concentration on risk taking of banks in South Asia. This study relates to South Asian countries due to their importance in emerging economy. Banking system of these countries is at the growing phase, with diverse strategies and stages of development (Hunjra et al., 2020c). During recent decades, emerging countries normally display financial markets with increasingly developing economies, while having political, social, and economic progress (Boubaker \& Nguyen, 2014). In 2016, the World Bank reported that South Asian countries had the fastest economic growth in the world (World Bank, 2016). In addition, Asian banks are the key sources of financing for private businesses (Hsieh et al., 2013). Banks in South Asia have transformed from the last few years due to privatization and restrictions on financial policies. As the banking sector is the backbone for these nations, so a healthy and prosperous economic system requires a stable and profitable banking sector. For survival and maintaining profitability in a competitive banking environment, banks in these countries have focused on diversifying their sources of income from traditional to non-traditional. As a result, non-traditional income has increased, and it is considered a good source of banks' income in South Asia (Nisar et al., 2018).

Doumpos et al. (2016) explain the profitability and fruitfulness of revenue diversification of banks for developing and developed nations. The researchers conclude that it is more fruitful for developing nations. Banks and financial institutions face risk in their daily operations that may lead to banking industry. Therefore, it is necessary to implement effective practices for survival and success of banking industry. This strongly prompted the study to be carried out in the South Asian countries. With the lack of efficient capital markets and low level of market capitalization, as compared to developed countries, the banking sector represents the only alternate financing source in developing countries (Nisar et al., 2015). Based on these studies, it can be said that emerging economies face more risks, there is a need to evaluate the effect of the non-traditional income source and revenue concentration on bank risk. This impact has been investigated based on four selected South Asian countries, i.e. Pakistan, Sri Lanka, India and Bangladesh.

Capital adequacy ratio is an important element, because if banks increase their capital adequacy limit, it helps to decrease bank risk (Ashraf et al., 2016). In addition, bank size and bank loans are essential for managing bank risk. Large banks are more stable and effective, as compared to small banks, therefore, they contribute more to the financial system stabilization (De Haan \& Poghosyan, 2012). Further, a bank having more revenue portfolios and loan growth has more risk compared to banks having a medium or low level of loan growth and revenue concentration. Findings of this study suggest that revenue concentration and non-interest income significantly influence bank risk. Therefore, this study helps the management of banks focus on managing income sources to reduce risk.

Sections 1 and 2 of this study provide brief literature and methodology, respectively. The results are presented in section 3, followed by conclusions and insights for further research. 


\section{LITERATURE REVIEW AND HYPOTHESES DEVELOPMENT}

Non-interest income is a crucial element for banks to diversify their income (Huang \& Chen, 2006). There is a need to combine both types of income - interest and non-interest sources - in such a way that reduces bank risk. When banks choose non-interest income, this may directly influence the risk of these banks. DeYoung and Roland (2001) investigate whether fee-based income has any influence on US based commercial bank's profitability and risk and find that it significantly enhances bank revenue volatility. Stiroh and Rumble (2006) report a significant positive relationship between non-traditional source income and risk. Lepetit et al. (2008) explain that increased bank risk is not due to trading activities, but due to commission and fee-charging exercises. They confirm that an increase in non-interest income enhances the operating risk of banks. This additional risk particularly arises from fee and commission incomes of banks. Further, when there is an increase in the amount of non-interest income, the problem of managing the diverse source of income arises, which also increases total risk.

Sanya and Wolfe (2011) examine the effect of non-traditional income sources on performance and insolvency risk and conclude that interest and non-interest sources of income decrease bank's insolvency risk. Brunnermeier et al. (2012) identify that systematic risk of banks increases due to the high rank of non-interest income. Lee et al. (2014) conducted a study relating to the banks of different countries in Asia and reported that non-interest income decreased bank risk. Williams (2016) analyze that for Australian banks, non-interest income positively influences risk of banks. Maudos (2017) also investigates the same relationship between non-interest income and risk taking of European banks and concludes a positive relationship between non-interest income and bank risk. Banks can use non-interest income as a source of earning, considering the risk attached to it. Based on the above literature, the following hypothesis is developed:

\section{$H_{1}: \quad$ Non-interest income has a positive effect on bank risk.}

Banks run their businesses by diversifying their income into traditional and non-traditional sources. A bank uses an income diversification strategy to decrease the level of risk. The diversification of bank income mainly emphasizes the non-interest source of income (Allen \& Santomero, 2001). The diversification in a non-interest source of income helps to offset the decrease in interest source income since the Asian 1997 financial crisis. Banks in South Asia are diversifying their income source to manage the level of risk and increase returns. The concept of diversifying income relates to Markowitz (1952) portfolio theory, which argues that firms can reduce risk and increase return if they diversify their businesses. This signifies that business diversification strategy reduces risk and increases financial performance. However, diversification strategy relates to the concept of Agency Theory of Jensen and Meckling (1976). Managers diversify their business activities to improve their own skills for their personal gains even if diversifying their activities negatively affect the value of banks. Boot and Schmeits (2000) find that income diversification strategy decreases banks' risk. This helps them to decrease their financial distress costs by diversifying their activities into multiple products. To survive in a competitive environment, banks opt to diversify their incomes. Banks working in a competitive setting are more efficient and stable due to their diversification policy, which leads to increase in performance and returns based on risk. Competition leads banks to diversify their revenues through traditional and non-traditional activities (Amidu \& Wolfe, 2013).

DeYoung and Rice (2004) claim that banks with well operation management rely less on non-traditional income source than banks with inefficient management practices. This indicates the evidence of inverse agency impacts of decreased interest source income. Berger et al. (2010) confirm this view in China. Baele et al. (2007) argue that revenue diversification leads to an increase in systematic risk of a bank. De Jonghe (2010) and Fiordelisi et al. (2011) conduct studies in European banks and find a positive relationship between revenue diversification and bank risk. Gurbuz et al. (2013) find similar results. Nisar et al. (2018) observe that banks can get positive outputs if they diversify their revenues mainly in the non-interest source of income. This indicates that banks' diversification 
strategies help to improve financial outputs, which ultimately reduce risk. In this aspect, Mehmood et al. (2019) conduct a similar study and find that a corporate diversification strategy significantly influences firm financial performance. Further, there is a need to utilize resources more efficiently to implement a profitable diversification policy. Hunjra et al. (2020a) conclude that non-interest source incomes and implementation of diversification policies reduce risk-taking of banks. Based on the above discussion, the following hypothesis is developed:

\section{$H_{2}: \quad$ Revenue concentration has a negative effect on bank risk.}

In addition to non-interest income and revenue diversification, this study has also included bank size, capital adequacy ratio and loan growth as control variables. Haq and Heaney (2012) and Williams (2016) investigate the relationship between bank size and risk and conclude that bank size and risk are positively related to each other. A contradictory relationship is examined by Demsetz and Strahan (1997) and De Haan and Poghosyan (2012). They reported that large banks enjoy the benefits of reducing risk. The large banks get benefits of economies of scale and thus avoid risk. Furthermore, large-sized banks have more access to multiple borrowers and enjoy large deposits. Literature explains the importance of capital adequacy ratio in the risk-taking behavior of banks. Barth et al. (2004) document that when the government asks banks to overcome risk, the banks enhance the level of capital to meet legal requirements. Theoretically, the relationship between capital adequacy ratio and bank risk is still ambiguous.

Shrieves and Dahl (1992) and Altunbas et al. (2007) find a positive relationship between capital requirements and risk taking in US and European banks. In contrast, Konishi and Yasuda (2004) and Maji and De (2015) reveal a negative influence of capital requirements on bank risk in Japan and India. Ashraf et al. (2016) report similar outcomes. Nisar et al. (2018) explain that the capital adequacy ratio significantly and positively influences the risk-based profitability of banks. In this study, loan growth is also considered as a control variable. Foos et al. (2010) investigate a study and find that loan growth reduces risk related to interest income. Some studies show a positive effect of loan growth on bank risk (Kwan \& Eisenbeis, 1997; and Stiroh \& Rumble, 2006). This implies that when banks finance their assets with the loan amount, they hold less financial assets, which leads to enhanced risk level of banks.

\section{METHODOLOGY}

This study investigates the effects of non-interest income and revenue concentration on the risk of banks in South Asia - Pakistan, Sri Lanka, India and Bangladesh. This study also uses bank size, capital adequacy ratio and loan growth as control variables. Data for this study is extracted from DataStream, which consists of 30 banks from Pakistan, 25 from India, 17 from Bangladesh and 13 from Sri Lanka, for the period of 2009-2018. Bank risk is measured as the range-based volatility of return on total assets before tax defined as log (higher value - lower value) and the range-based volatility of profit before tax defined as log (higher value - lower value). Alizadeh et al. (2002) and Williams (2016) use the same proxies of bank risk. This study calculates non-interest income as the ratio of NII to total revenue of banks, as measured by Stiroh and Rumble (2006) and Williams (2016). Revenue concentration is measured based on the Herfindahl index, which is calculated as the sum of the squares of the revenue. Esho et al. (2005) apply the same to calculate revenue concentration. This study uses proxy of bank size (BS) as a natural log of total assets, as used by Williams (2016), Abdullah and Tan (2017) and Chen et al. (2017). Capital adequacy ratio (CAR) is the total capital to risk-weighted assets ratio (CRAR). Maji and De (2015) use the same calculation for capital adequacy ratio. Loan growth is calculated as the change in total loans and leases from the preceding period, expressed as a percentage (Kashif et al., 2016).

The following regression model is used for the analysis:

$$
\begin{aligned}
& B R_{i, t}=\alpha+\beta_{1} N I I_{i, t}+\beta_{2} R C_{i, t}+ \\
& +\beta_{3} B S_{i, t}+\beta_{4} C A R_{i, t}+\beta_{5} L G_{i, t}+\mu_{i, t},
\end{aligned}
$$

where $\alpha=$ intercept for each entity; $B R$ is bank risk, $i$ is bank and $t$ is time; NII is non-interest income; 
Table 1. Measurement of variables

\begin{tabular}{|c|c|c|c|}
\hline Variables & Symbols & Measurements & References \\
\hline Bank risk & $\begin{array}{l}\text { VROA } \\
\text { VPBT }\end{array}$ & $\begin{array}{l}\text { Range based volatility of return on assets before tax } \\
\text { defined as log (high-value - low value) } \\
\text { Range based volatility of profit before tax defined as log } \\
\text { (high value - low value) }\end{array}$ & Alizadeh et al. (2002), Williams (2016) \\
\hline $\begin{array}{l}\text { Non-interest } \\
\text { income }\end{array}$ & NII & Non-interest income over total revenue & Stiroh and Rumble (2006), Williams (2016) \\
\hline $\begin{array}{l}\text { Revenue } \\
\text { concentration }\end{array}$ & $\mathrm{RC}$ & $\begin{array}{l}\text { Herfindahl-Hirschman Index }(H H I) \text { based on sum of the } \\
\text { squares of revenue shares }\end{array}$ & Esho et al. (2005), Williams (2016) \\
\hline Bank Size & BS & Log of assets & $\begin{array}{l}\text { Williams (2016), Abdullah and Tan (2017), } \\
\text { Chen et al. (2017) }\end{array}$ \\
\hline $\begin{array}{l}\text { Capital } \\
\text { adequacy ratio }\end{array}$ & CAR & $C A R=($ Tier One + Tier 2 capital $) /$ risk weighted assets & Rime (2001), Maji and De (2015) \\
\hline Loan growth & LG & $L G=$ (Current value-Previous value / previous value) & Kashif et al. (2016) \\
\hline
\end{tabular}

$R C$ is revenue concentration; $B S$ is bank size; $C A R$ is the capital adequacy ratio; $L G$ is loan growth; $\beta$ is a coefficient for independent variables, and $\mu$ is an error term.

This study uses descriptive statistics, which summarizes the data followed by the correlation analysis to check multicollinearity. Furthermore, a two-step system dynamic panel regression is used to test hypotheses. The GMM technique explains the variation and bias concerning the endogeneity issues (Hunjra et al., 2020b). This study uses twostep dynamic panel estimation, which is appropriate for a short period and long cross-sectional data. The technique is developed by Arellano and Bond (1991) and Arellano and Bover (1995).

\section{RESULTS}

Table 2 presents the descriptive statistics and correlation analysis. The volatility of return on assets before tax (VROA) is a proxy for bank risk. The mean of VROA shows that banks of selected countries are facing a high level of risk with a negative
ROA, which shows that the banks need to manage risk. The volatility of banks' profit before tax is high with high variation in the values; this means that banks are facing more risk while generating earnings. Non-interest income as a proportion of total income shows that banks are more prone to the traditional way of income, i.e. interest income. However, due to changes in regulations of banks in the competitive environment, banks are opting non-interest income. This increasing trend of generating non-interest income also shows that banks are diversifying their revenue sources to reduce risk. The average value of revenue concentration suggests that banks maximize benefits to offset additional expenses while generating diverse sources of income. Bank size suggests that banks have a stable investment in their total assets with a less variation in the values of investment in assets. The average value of capital adequacy ratio suggests that banks in selected countries fulfill the required limit, as per Basel II, the required limit of adequacy ratio of capital is $8 \%$ (Chen \& Hsu, 2014). Therefore, the banks of selected countries meet the required level of capital adequacy. However, some of the banks of selected countries do not fulfill the

Table 2. Descriptive statistics and correlation analysis

\begin{tabular}{|c|c|c|c|c|c|c|c|c|c|}
\hline Variables & Mean & S.D & VROA & VPBT & NII & $\mathrm{RC}$ & BS & CAR & LG \\
\hline VROA & -4.684 & 1.523 & 1.000 & - & - & - & - & - & - \\
\hline VPBT & 21.236 & 1.502 & 0.059 & 1.000 & - & - & - & - & - \\
\hline NII & 0.312 & 0.781 & 0.049 & -0.076 & 1.000 & - & - & - & - \\
\hline$R C$ & 2142.721 & 21.850 & 0.021 & -0.045 & -0.035 & 1.000 & - & - & - \\
\hline$B S$ & 11.227 & 0.781 & -0.492 & 0.571 & -0.121 & -0.030 & 1.000 & - & - \\
\hline$C A R$ & 0.164 & 0.123 & 0.049 & -0.327 & 0.018 & -0.001 & -0.307 & 1.000 & - \\
\hline$L G$ & 0.161 & 0.460 & -0.020 & 0.014 & -0.086 & -0.126 & 0.020 & -0.005 & 1.000 \\
\hline
\end{tabular}

Note: $V R O A=$ Volatility of return on assets, $V P B T=$ Volatility of profit before tax,$N I I=$ Non-interest income, $R C=$ Revenue concentration, $B S=$ Bank size, $C A R=$ Capital adequacy ratio; $L G=$ Loan growth . 
minimum required level of capital adequacy as they cannot follow capital regulation for their system. Results also suggest that banks are still at the growing stage of advancing loans. This indicates that banks are not taking much risk in terms of their loan activities.

Table 3. Multicollinearity test

\begin{tabular}{l|c|c}
\hline \multicolumn{1}{c|}{ Variables } & VIF & 1/VIF \\
\hline CAR & 1.110 & 0.901 \\
\hline$B S$ & 1.100 & 0.909 \\
\hline$R C$ & 1.090 & 0.914 \\
\hline LGS & 1.080 & 0.930 \\
\hline LG & 1.040 & 0.957 \\
\hline NII & 1.030 & 0.972 \\
\hline
\end{tabular}

Note: VIF = Variance Inflation Factor.

The study reports Variance Inflation Factor (VIF) and Tolerance (1/VIF) to verify multicollinearity in the model in Table 3. The study confirms no multicollinearity problem in the model, since the values of VIF are well within the limit of 10 (Shan, 2015). This study further explains the correlation results in Table 2. The results suggest that there is not a sign of the high correlation between the variables.

Table 4. Two-step dynamic panel regression

\begin{tabular}{|c|c|c|c|c|}
\hline \multirow{2}{*}{ Variables } & \multicolumn{2}{|c|}{ Model 1} & \multicolumn{2}{|c|}{ Model 2} \\
\hline & Coef. & t-values & Coef. & t-values \\
\hline L1 & $0.747 * * *$ & $(22.520)$ & $0.581 * * *$ & $(28.110)$ \\
\hline$\angle 2$ & $-0.072 * * *$ & $(-8.560)$ & $-0.152 * * *$ & $(-10.490)$ \\
\hline NII & 0.024 & $(1.550)$ & $-0.033^{* * *}$ & $(-3.230)$ \\
\hline$R C$ & $0.00001 * * *$ & $(8.010)$ & $0.000008^{* * *}$ & $(7.100)$ \\
\hline$B S$ & $-1.061^{* * *}$ & $(-7.070)$ & $0.336^{* * *}$ & $(4.220)$ \\
\hline CAR & 1.275 & $(1.450)$ & $0.898 * *$ & $(2.240)$ \\
\hline$L G$ & $0.088^{* *}$ & $(2.000)$ & 0.051 & (1.090) \\
\hline C & $10.031^{* * *}$ & $(4.040)$ & $8.127^{* * *}$ & $(8.230)$ \\
\hline Sargan & 8.618 & - & 11.081 & - \\
\hline$A R_{1}(\mathrm{p}$-value) & 0.039 & - & 0.002 & - \\
\hline $\begin{array}{l}A R_{2} \\
\text { (p-value) }\end{array}$ & 0.413 & - & 0.387 & - \\
\hline
\end{tabular}

Note: $V R O A=$ Volatility of return on assets, $V P B T=$ Volatility of profit before tax, $L 1$ - First lag of VROA and VPBT, $L 2-$ Second lag of $V R O A$ and $V P B T, N I I=$ Non-interest income, $R C=$ Revenue concentration, $B S=$ Bank size, $C A R=$ Capital adequacy ratio; $\mathrm{LG}=$ Loan growth $\mathrm{C}=$ Constant, Model 1 represents $V R O A$ as a dependent variable, Model 2 represents $V P B T$ as a dependent variable, Sargan = Test for over identifying restrictions, $A R_{1}=$ Arellano-Bond first order autocorrelation, $A R_{2}=$ Arellano-Bond second order autocorrelation. $*, * *$ and ${ }^{2} * *$ denote the level of significance at $10 \%, 5 \%$ and $1 \%$, respectively.

Table 4 explains the impact of non-interest income and revenue concentration on bank risk. In this study, GMM is used to handle endogeneity issues. The study uses the Sargan test to validate instruments. Insignificant outcomes indicate that instruments used in this study are valid. Further, the study uses the Arellano-Bond test to verify autocorrelation. $\mathrm{AR}_{2}$ results reveal insignificant values. Therefore, the study confirms no autocorrelation. The findings of the study reveal that non-interest income has a negative impact on banks' risk (volatility of profit before tax), whereas it has an insignificant relationship with the volatility of return on assets. Negative impact reveals that non-interest income does not increase the volatility of banks' profit before tax because of the dominance of the traditional way of generating income for commercial banks in South Asian countries. The findings of this study also indicate that banks in South Asian countries are more concerned about non-interest income in order to reduce risk when it is measured by volatility of profit before tax. The study finds the similar results in Sanya and Wolfe (2011) and Lee et al. (2014). Further, it suggests that when banks choose diversification in their income sources, they take benefit from diversified incomes to reduce risk. Revenue concentration has a significant and positive effect on both measures of banks risks. This confirms that the complexity in combining different revenue sources creates agency cost that leads to offset benefits from diversifying revenue sources and, as a result, increases risk (Acharya et al., 2006).

Bank size has a significant impact on the volatility of return on assets with a negative coefficient. This suggests that large-sized banks are either not concerned about investing in assets with more risk or they efficiently manage the risk. This also explains that large-sized banks are able to diversify their operations due to having more skills, and manage risk more efficiently (Rashid \& Khalid, 2018). The negative effect of bank size on risk is aligned with the findings of Aggarwal and Jacques (1998). However, the study finds that bank size has a significant and positive influence on the volatility of profit before tax. Capital adequacy ratio is used in this study to calculate the level of capital requirements. It positively affects the volatility of profit before tax. This indicates that banks with higher risks are also compensated with the increased capital adequacy ratio. A positive effect of the 
Table 5. Country-wise analysis

\begin{tabular}{|c|c|c|c|c|c|c|c|c|}
\hline \multirow{2}{*}{ Variables } & \multicolumn{2}{|c|}{ Pakistan } & \multicolumn{2}{|c|}{ India } & \multicolumn{2}{|c|}{ Sri Lanka } & \multicolumn{2}{|c|}{ Bangladesh } \\
\hline & Model 1 & Model 2 & Model 1 & Model 2 & Model 1 & Model 2 & Model 1 & Model 2 \\
\hline L1 & $\begin{array}{c}0.747 * * * \\
(12.520)\end{array}$ & $\begin{array}{c}0.581^{* * *} \\
(28.110)\end{array}$ & $\begin{array}{c}0.491^{* * *} \\
(33.490)\end{array}$ & $\begin{array}{c}0.546^{* * *} \\
(29.300)\end{array}$ & $\begin{array}{c}0.591^{* * *} \\
(5.570)\end{array}$ & $\begin{array}{c}0.246 \\
(0.810)\end{array}$ & $\begin{array}{c}0.217^{* * *} \\
(3.100)\end{array}$ & $\begin{array}{l}0.131^{*} \\
(1.930)\end{array}$ \\
\hline$\angle 2$ & $\begin{array}{c}-0.072^{* * *} \\
(-8.560)\end{array}$ & $\begin{array}{c}-0.152^{* * *} \\
(-10.490)\end{array}$ & $\begin{array}{c}-0.088^{* * *} \\
(-11.570)\end{array}$ & $\begin{array}{c}-0.046 * * * \\
(-4.690)\end{array}$ & $\begin{array}{l}-0.044 \\
(-0.190)\end{array}$ & $\begin{array}{c}-0.461^{* *} \\
(-2.580)\end{array}$ & $\begin{array}{c}-0.181^{* * *} \\
(-3.550)\end{array}$ & $\begin{array}{c}-0.307^{* *} \\
(-2.780)\end{array}$ \\
\hline NII & $\begin{array}{c}0.024 \\
(1.550)\end{array}$ & $\begin{array}{c}-0.033^{* * *} \\
(-3.230)\end{array}$ & $\begin{array}{l}-0.169 \\
(-0.090)\end{array}$ & $\begin{array}{l}-3.279 * \\
(-1.900)\end{array}$ & $\begin{array}{l}-1.955 \\
(-0.260)\end{array}$ & $\begin{array}{l}-1.920 \\
(-0.780)\end{array}$ & $\begin{array}{c}-4.216^{* *} \\
(-2.410)\end{array}$ & $\begin{array}{l}-1.488 \\
(-1.600)\end{array}$ \\
\hline$R C$ & $\begin{array}{c}0.001^{* * *} \\
(8.010)\end{array}$ & $\begin{array}{c}0.001^{* * *} \\
(7.100)\end{array}$ & $\begin{array}{c}0.000 \\
(0.050)\end{array}$ & $\begin{array}{c}-0.003^{* *} \\
(-2.340)\end{array}$ & $\begin{array}{l}-0.009 \\
(-0.130)\end{array}$ & $\begin{array}{l}-0.003 \\
(-1.250)\end{array}$ & $\begin{array}{c}0.000 \\
(0.610)\end{array}$ & $\begin{array}{c}0.000 \\
(-1.260)\end{array}$ \\
\hline$B S$ & $\begin{array}{c}-1.061^{* * *} \\
(-52.070)\end{array}$ & $\begin{array}{c}0.336^{* * *} \\
(4.220)\end{array}$ & $\begin{array}{c}-0.326^{* * *} \\
(-12.770)\end{array}$ & $\begin{array}{c}1.201^{* * *} \\
(45.210)\end{array}$ & $\begin{array}{l}-0.120 \\
(-0.200)\end{array}$ & $\begin{array}{c}3.006^{* *} \\
(2.570)\end{array}$ & $\begin{array}{c}-1.747^{* * *} \\
(-2.750)\end{array}$ & $\begin{array}{l}-1.096^{*} \\
(-1.850)\end{array}$ \\
\hline CAR & $\begin{array}{c}1.275 \\
(1.450)\end{array}$ & $\begin{array}{c}0.898^{* * *} \\
(2.240)\end{array}$ & $\begin{array}{c}-0.728^{* * *} \\
(-3.290)\end{array}$ & $\begin{array}{c}2.263^{* * *} \\
(5.160)\end{array}$ & $\begin{array}{l}10.211 \\
(1.110)\end{array}$ & $\begin{array}{l}-0.573 \\
(-0.120)\end{array}$ & $\begin{array}{l}-8.461 \\
(-1.120)\end{array}$ & $\begin{array}{l}12.272 \\
(1.310)\end{array}$ \\
\hline$L G$ & $\begin{array}{l}0.088^{* *} \\
(2.000)\end{array}$ & $\begin{array}{c}0.051 \\
(1.090)\end{array}$ & $\begin{array}{c}-0.248^{* * *} \\
(-7.740)\end{array}$ & $\begin{array}{c}-0.201^{* * *} \\
(-6.460)\end{array}$ & $\begin{array}{c}0.132 \\
(0.620)\end{array}$ & $\begin{array}{l}-0.015 \\
(-0.140)\end{array}$ & $\begin{array}{l}-0.369 \\
(-0.910)\end{array}$ & $\begin{array}{c}0.994^{* * *} \\
(2.660)\end{array}$ \\
\hline C & $\begin{array}{c}10.031^{* * *} \\
(48.040)\end{array}$ & $\begin{array}{c}8.127 * * * \\
(8.230)\end{array}$ & $\begin{array}{l}1.013 \\
(0.770)\end{array}$ & $\begin{array}{l}-0.464 \\
(-0.500)\end{array}$ & $\begin{array}{l}-1.518 \\
(-0.170)\end{array}$ & $\begin{array}{l}-5.530 \\
(-0.670)\end{array}$ & $\begin{array}{c}17.338^{* *} \\
(2.290)\end{array}$ & $\begin{array}{c}35.744^{* * * *} \\
(4.510)\end{array}$ \\
\hline Sargan & 8.086 & 10.418 & 6.385 & 7.598 & 3.370 & 4.252 & 4.041 & 8.541 \\
\hline$A R_{1}$ ( $p$-value) & 0.048 & 0.015 & 0.003 & 0.061 & 0.047 & 0.039 & 0.073 & 0.007 \\
\hline$A R_{2}$ (p-value) & 0.310 & 0.219 & 0.313 & 0.504 & 0.177 & 0.611 & 0.513 & 0.389 \\
\hline
\end{tabular}

Note: $V R O A=$ Volatility of return on assets, $V P B T=$ Volatility of profit before tax, $L 1-$ First lag of VROA and VPBT, $L 2-$ Second lag of $V R O A$ and $V P B T, N I I=$ Non-interest income, $R C=$ Revenue concentration, $B S=$ Bank size, $C A R=$ Capital adequacy ratio; $L G=$ Loan growth, $C=$ Constant, Model 1 represents VROA as a dependent variable, Model 2 represents VPBT as a dependent variable, Sargan $=$ Test for over identifying restrictions, $A R_{1}=$ Arellano-Bond first order autocorrelation, $A R_{2}=$ Arellano-Bond second order autocorrelation. ${ }^{*}, * *$ and ${ }^{* * *}$ denote the level of significance at $10 \%, 5 \%$ and $1 \%$, respectively.

capital adequacy ratio follows the results of Blum (1999) and Altunbas et al. (2007). However, the capital adequacy ratio does not reveal any significant effect on the volatility of return on assets. The loan growth ratio reveals mixed results. The findings show that loan growth has a positive effect on the volatility of return on assets, whereas it has an insignificant effect on the volatility profit before taxes. The positive effect on risk shows that firms holding more amount of assets are financed by loans and face more risk because they hold less amount of financial assets.

Table 5 presents country-wise analysis to check the robustness of results. The study reveals an insignificant result of the Sargan test showing that instruments are valid. The results of $\mathrm{AR}_{2}$ reveal insignificant $\mathrm{p}$-values, which signify that there is no autocorrelation. The study finds mixed outputs depending on the regulations and implementation of the regulatory system in each country. Generally, non-interest in- come shows a significant and negative effect on bank risk for Pakistan, India and Bangladesh. The negative findings follow the results of Lee et al. (2014), where they show that non-interest income decreases the risk of South Asian countries that generate a middle or low-income level. In addition, non-interest income has a insignificant effect on bank risk in Sri Lanka. Therefore, individual analysis shows that banks in Sri Lanka are not much concerned to generate non-interest income; rather they are concerned about generating interest source of income. With respect to Pakistan, revenue concentration shows a significant and positive effect on bank risk, which explains that banks in Pakistan are more risky as they depend on diversified sources of incomes. Findings relate to the outputs of Maudos (2017) who documents an increase in risk when banks increase non-interest income in their revenue concentration. For India, revenue concentration has a significant and negative effect on bank risk, which is measured in this study as the volatility of profit before tax- 
es. However, revenue concentration does not affect the bank risk in Sri Lanka and Bangladesh. Capital adequacy ratio shows mixed findings but banks of selected countries are fulfilling the minimum requirements of capital adequacy. However, it has a significant effect on bank risk for India, while this ratio shows a significant and positive effect on the volatility of profit before taxes for Pakistan. In the context of Sri Lanka and Bangladesh, it has an insignificant effect on bank risk. Banks size generally shows a negative influence on bank risk, which means that large banks are able to reduce risk. This also suggests that large banks in South Asia invest less in risky assets. Further, large banks are more capable of managing risk and they have better opportunities to diversify their portfolios. The results of this study are similar to those of Rashid and Khalid (2018). In addition, loan growth shows different results depending on the nature of bank risk measures and the nature of implementing loan-related activities.

\section{CONCLUSION}

This study aims to examine the impact of non-interest income and revenue concentration on bank risk using the Generalized Method of Moments (GMM) to analyze the results. The results of the study reveal that non-interest income has a negative impact on bank risk. Managers of banks can focus on non-interest income along with traditional source of income to improve the profitability of their banks and minimize their risk levels. The diverseness of the banking industry in the modern era has become a subject of interest for the top management of banks, supervisors, directors, shareholders and stakeholders. In addition, non-interest income does not influence the volatility of return on assets. These mixed findings show that banks in South Asia are still at a growing stage of promoting non-interest source of income. Revenue concentration shows that when banks diversify their revenues, risk increases, which is against the conventional discussion that an increase in the portfolio of income sources leads to a decrease in risk taking.

The results of this study help managers to improve the financial outlook of their banks by controlling revenue diversification and risk. The findings also present policy implications that banks may utilize non-interest income in a profitable way in order to reduce risk. Further, they should focus on non-interest sources of income along with traditional source income to prevail in a competitive banking environment. Revenue concentration increases bank risk taking. Therefore, bank managers should manage complexity by combining revenue sources to control agency costs, which reduce risk. Thus, when banks expand their income structure, they should align it with available resources.

\section{AUTHOR CONTRIBUTIONS}

Conceptualization: Ahmed Imran Hunjra, Qasim Zureigat, Rashid Mehmood.

Data curation: Qasim Zureigat, Tahar Tayachi.

Formal analysis: Qasim Zureigat, Rashid Mehmood.

Investigation: Qasim Zureigat, Rashid Mehmood.

Methodology: Ahmed Imran Hunjra, Tahar Tayachi, Rashid Mehmood.

Project administration: Ahmed Imran Hunjra, Tahar Tayachi.

Resources: Tahar Tayachi, Rashid Mehmood.

Software: Tahar Tayachi, Rashid Mehmood.

Supervision: Ahmed Imran Hunjra, Tahar Tayachi.

Validation: Qasim Zureigat, Tahar Tayachi, Rashid Mehmood.

Writing - original draft: Ahmed Imran Hunjra, Tahar Tayachi, Rashid Mehmood.

Writing - reviewing \& editing: Qasim Zureigat, Tahar Tayachi. 


\section{REFERENCES}

1. Abdullah, N., \& Tan, Y. (2017). Profitability of Commercial Banks revisited: New Evidence from oil and non-oil exporting countries in the MENA region. Investment Management and Financial Innovations, 14(3), 6273. http://dx.doi.org/10.21511/ imfi.14(3).2017.06

2. Acharya, V. V., Hasan, I., \& Saunders, A. (2006). Should banks be diversified? Evidence from individual bank loan portfolios. The Journal of Business, 79(3), 1355-1412. https://www.jstor.org/ stable/10.1086/500679

3. Aggarwal, R., \& Jacques, K. T. (1998). Assessing the impact of prompt corrective action on bank capital and risk. Economic Policy Review, 4(3), 23-32. http://dx.doi. org/10.2139/ssrn.1024839

4. Alizadeh, S., Brandt, M. W., \& Diebold, F. X. (2002). Range-based estimation of stochastic volatility models. The Journal of Finance, 57(3), 1047-1091. https://doi. org/10.1111/1540-6261.00454

5. Allen, F., \& Santomero, A. M. (2001). What do financial intermediaries do? Journal of Banking \& Finance, 25(2), 271-294. https://doi.org/10.1016/S03784266(99)00129-6

6. Altunbas, Y., Carbo, S., Gardener, E. P., \& Molyneux, P. (2007). Examining the relationships between capital, risk and efficiency in European banking. European Financial Management, 13(1), 4970. https://doi.org/10.1111/j.1468 036X.2006.00285.x

7. Amidu, M., \& Wolfe, S. (2013). Does bank competition and diversification lead to greater stability? Evidence from emerging markets. Review of Development Finance, 3(3), 152-166. https://doi. org/10.1016/j.rdf.2013.08.002

8. Arellano, M., \& Bond, S. (1991). Some tests of specification for panel data: Monte Carlo evidence and an application to employment equations. The Review of Economic Studies, 58(2), 277-297. https://doi. org/10.2307/2297968
9. Arellano, M., \& Bover, O. (1995). Another look at the instrumental variable estimation of errorcomponents models. Journal of Econometrics, 68(1), 29-51. https://doi.org/10.1016/03044076(94)01642-D

10. Ashraf, B., Arshad, S., \& Hu, Y. (2016). Capital regulation and bank risk-taking behavior: evidence from Pakistan. International Journal of Financial Studies, 4(3), 16. https://doi. org/10.3390/ijfs4030016

11. Baele, L., De Jonghe, O., \& Vennet, R. V. (2007). Does the stock market value bank diversification? Journal of Banking \& Finance, 31(7), 1999-2023. https://doi.org/10.1016/j.jbankfin.2006.08.003

12. Barth, J. R., Caprio G., \& Levine, R. (2004). Bank regulation and supervision: What works best? Journal of Financial Intermediation, 13(2), 205-248. https://doi. org/10.1016/j.jfi.2003.06.002

13. Berger, A. N., Hasan, I., \& Zhou, M. (2010). The effects of focus versus diversification on bank performance: Evidence from Chinese banks. Journal of Banking \& Finance, 34(7), 1417-1435. https://doi.org/10.1016/j.jbankfin.2010.01.010

14. Blum, J. (1999). Do capital adequacy requirements reduce risks in banking? Journal of Banking \& Finance, 23(5), 755-771. https://doi.org/10.1016/S03784266(98)00113-7

15. Boot, A. W., \& Schmeits, A. (2000) Market discipline and incentive problems in conglomerate firms with applications to banking. Journal of Financial Intermediation, 9(3), 240-273. https://doi. org/10.1006/jin.2000.0287

16. Boubaker, S., \& Nguyen, D. K. (2014). Corporate governance in emerging markets. Springer.

17. Brunnermeier, M. K., Dong G. N., \& Palia, D. (2012). Banks' Non-Interest Income and Systemic Risk (AFA 2012 Chicago Meetings Paper). Princeton University.
Retrieved from https://papers.ssrn. com/sol3/papers.cfm?abstract_ id $=1786738$

18. Chen, Y. K., Ho, A. Y.-F., \& Hsu, C. L. (2014). Are Bank Capital Buffers Cyclical? Evidence for Developed and Developing Countries. Journal of Financial Studies, 22(3), 27-56. Retrieved from http://www.jfs.org.tw/ index.php/jfs/article/viewArticle/2014140

19. Chen, Z., Liu, F. H., Opong, K., \& Zhou, M. (2017). Short-term safety or long-term failure? Empirical evidence of the impact of securitization on bank risk. Journal of International Money and Finance, 72, 48-74. https://doi.org/10.1016/j.jimonfin.2016.12.003

20. De Haan, J., \& Poghosyan, T. (2012). Size and earnings volatility of US bank holding companies. Journal of Banking and Finance, 36(11), 3008-3016. https://doi.org/10.1016/j.jbankfin.2012.07.008

21. De Jonghe, O. (2010). Back to the basics in banking? A microanalysis of banking system stability. Journal of Financial Intermediation, 19(3), 387417. https://doi.org/10.1016/j. jfi.2009.04.001

22. Deesomsak, R., Paudyal, K., \& Pescetto, G. (2004). The determinants of capital structure: Evidence from the Asia Pacific region. Journal of Multinational Financial Management, 14(4/5), 387-405. https://doi.org/10.1016/j. mulfin.2004.03.001

23. Demsetz, R. S., \& Strahan, P. E. (1997). Diversification, size, and risk at bank holding companies. Journal of Money, Credit, and Banking, 29(3), 300-313. Retrieved from https://www.jstor.org/ stable/2953695

24. DeYoung, R., \& Rice, T. (2004). Noninterest income and financial performance at US commercial banks. Financial Review, 39(1), 101-127. https://doi.org/10.1111/ j.0732-8516.2004.00069.x 
25. DeYoung, R., \& Roland, K. P. (2001). Product mix and earnings volatility at commercial banks: Evidence from a degree of total leverage model. Journal of Financial Intermediation, 10(1), 54-84. https://doi.org/10.1006/ jifin.2000.0305

26. DeYoung, R., \& Torna, G. (2013). Nontraditional banking activities and bank failures during the financial crisis. Journal of Financial Intermediation, 22(3), 397-421. https://doi.org/10.1016/j. jfi.2013.01.001

27. Doumpos, M., Gaganis, C., \& Pasiouras, F. (2016). Bank diversification and overall financial strength: International evidence. Financial Markets, Institutions \& Instruments, 25(3), 169-213. https://doi.org/10.1111/ fmii. 12069

28. Elsas, R., Hackethal, A., \& Holzhauser, M. (2010). The anatomy of bank diversification. Journal of Banking \& Finance, 34(6), 1274-1287. https://doi.org/10.1016/j.jbankfin.2009.11.024

29. Esho, N., Kofman, P., \& Sharpe, I. G. (2005). Diversification, fee income, and credit union risk. Journal of Financial Services Research, 27(3), 259-281. https:// doi.org/10.1007/s10693-0051804-0

30. Fiordelisi, F., Marques-Ibanez, D., \& Molyneux, P. (2011) Efficiency and risk in European banking. Journal of Banking \& Finance, 35(5), 1315-1326. https://doi.org/10.1016/j.jbankfin.2010.10.005

31. Foos, D., Norden, L., \& Weber, M. (2010). Loan growth and riskiness of banks. Journal of Banking and Finance, 34(12), 2929-2940. https://doi.org/10.1016/j.jbankfin.2010.06.007

32. Gurbuz, A. O., Yanik, S., \& Ayturk, Y. (2013). Income diversification and bank performance: Evidence from Turkish banking sector. Journal of BRSA Banking and Financial Markets, 7(1), 9-29. Retrieved from https://www.bddk. org.tr/ContentBddk/BddkDergi/ dergi_0013_03.pdf
33. Gutierrez-Lopez, C., \& AbadGonzalez, J. (2020). Sustainability in the Banking Sector: A Predictive Model for the European Banking Union in the Aftermath of the Financial Crisis. Sustainability, 12(6), 2566. https://doi.org/10.3390/ su12062566

34. Haq, M., \& Heaney, R. (2012). Factors determining European bank risk. Journal of International Financial Markets, Institutions and Money, 22(4), 696-718. https://doi. org/10.1016/j.intfin.2012.04.003

35. Hidayat, W. Y., Kakinaka, M., \& Miyamoto, H. (2012). Bank risk and non-interest income activities in the Indonesian banking industry. Journal of Asian Economics, 23(4), 335-343. https://doi.org/10.1016/j.asieco.2012.03.008

36. Hsieh, M. F., Chen, P. F., Lee, C. C., \& Yang, S. J. (2013). How does diversification impact bank stability? The role of globalization, regulations, and governance environments. Asia-Pacific Journal of Financial Studies, 42(5), 813-844. https://doi.org/10.1111/ ajfs. 12032

37. Huang, L. W., \& Chen, Y. K. (2006). Does Bank Performance Benefit from Non-traditional Activities? A Case of Noninterest Incomes in Taiwan Commercial Banks. Asian Journal of Management and Humanity Sciences, 1(3), 359-378. http:// dx.doi.org/10.6413/AJMHS. 200610.0359

38. Hunjra, A. I., Hanif, M. Mehmood, R., \& Nguyen, L. V. (2020a). Diversification, corporate governance, regulation and bank risk-taking. Journal of Financial Reporting and Accounting, 18(3). https://doi.org/10.1108/JFRA-032020-0071

39. Hunjra, A. I., Mehmood, R., \& Tayachi, T. (2020b). How Do Corporate Social Responsibility and Corporate Governance Affect Stock Price Crash Risk? Journal of Risk and Financial Management, 13(2), 30. https://doi. org/10.3390/jrfm13020030
40. Hunjra, A. I., Zureigat, Q., \& Mehmood, R. (2020c). Impact of capital regulation and market discipline on capital ratio selection: A cross country study. International Journal of Financial Studies, 8(2), 21. https:// doi.org/10.3390/ijfs8020021

41. Jensen, M. C., \& Meckling, W. H., (1976). Theory of the firm: Managerial behavior, agency costs, and capital structure. In K. Brunner (Ed.), Economics Social Institutions. Rochester Studies in Economics and Policy Issues (Vol 1). Springer, Dordrecht. https:// doi.org/10.1007/978-94-009-92573_8

42. Kashif, M., Iftikhar, S. F., \& Iftikhar, K. (2016). Loan growth and bank solvency: evidence from the Pakistani banking sector. Financial Innovation, 2(1), 22. https://doi.org/10.1186/s40854016-0043-8

43. Konishi, M., \& Yasuda, Y. (2004). Factors affecting bank risk taking: Evidence from Japan. Journal of Banking \& Finance, 28(1), 215-232. https://doi.org/10.1016/S03784266(02)00405-3

44. Kwan, S., \& Eisenbeis, R. A. (1997). Bank risk, capitalization, and operating efficiency. Journal of Financial Services Research, 12(23), 117-131. https://doi. org/10.1023/A:1007970618648

45. Lee, C. C., Yang, S. J., \& Chang, C. H. (2014). Non-interest income, profitability, and risk in banking industry: A crosscountry analysis. The North American Journal of Economics and Finance, 27, 48-67. https://doi. org/10.1016/j.najef.2013.11.002

46. Lepetit, L., Nys, E., Rous, P., \& Tarazi, A. (2008). The expansion of services in European banking: Implications for loan pricing and interest margins. Journal of Banking \& Finance, 32(11), 2325 2335. https://doi.org/10.1016/j. jbankfin.2007.09.025

47. Maji, S. G., \& De, U. K. (2015) Regulatory capital and risk of Indian banks: a simultaneous equation approach. Journal of Financial Economic Policy, 7(2), 140-156. https://doi.org/10.1108/ JFEP-06-2014-0038 
48. Markowitz, H. (1952). Portfolio selection. The Journal of Finance 7(1), 77-91. https://doi. org/10.1111/j.1540-6261.1952. tb01525.x

49. Maudos, J. (2017). Income structure, profitability and risk in the European banking sector: The impact of the crisis. Research in International Business and Finance, 39(A), 85-101. https://doi. org/10.1016/j.ribaf.2016.07.034

50. Mehmood, R., Hunjra, A. I., \& Chani, M. I. (2019). The Impact of Corporate Diversification and Financial Structure on Firm Performance: Evidence from South Asian Countries. Journal of Risk and Financial Management, 12(1), 49. https://doi.org/10.3390/ jrfm12010049

51. Nisar, S., Peng, K., Wang, S., \& Ashraf, B. (2018). The impact of revenue diversification on bank profitability and stability: Empirical evidence from South Asian countries. International Journal of Financial Studies, 6(2), 40. https:// doi.org/10.3390/ijfs6020040

52. Nisar, S., Susheng, W., Jaleel, A., $\&$ Ke, P. (2015). Determinants of bank's profitability in Pakistan: A latest panel data evidence. International Journal of Economics, Commerce and Management, 3(4), 1-16. Retrieved from http:// ijecm.co.uk/wp-content/uploads/2015/04/3429.pdf

53. Rashid, A., \& Khalid, M. (2018). An Assessment of Bank Capital Effects On Bank-Risk-Taking In Pakistan. Pakistan Journal of Applied Economics, 28(2), 213-234. Retrieved from http://www.aerc.edu. pk/wp-content/uploads/2018/12/2. Paper-839-RASHID-III-1.pdf

54. Rime, B. (2001). Capital requirements and bank behavior: Empirical evidence for Switzerland. Journal of Banking \& Finance, 25(4), 789-805. https://doi. org/10.1016/S0378-4266(00)001059

55. Sanya, S., \& Wolfe, S. (2011).

Can banks in emerging economies benefit from revenue diversification? Journal of Financial Services Research, 40(1-2), 79-101. https://doi.org/10.1007/s10693-0100098-Z

56. Shan, Y. G. (2015). Value relevance, earnings management and corporate governance in China. Emerging Markets Review, 23, 186-207. https://doi.org/10.1016/j. ememar.2015.04.009

57. Shrieves, R. E., \& Dahl, D. (1992). The relationship between risk and capital in commercial banks. Journal of Banking \& Finance, 16(2), 439457. https://doi.org/10.1016/03784266(92)90024-T
58. Stiroh, K. J. (2006). A portfolio view of banking with interest and noninterest activities. Journal of Money, Credit, and Banking, 38(5), 1351-1361. Retrieved from https:// www.jstor.org/stable/3839009

59. Stiroh, K. J., \& Rumble, A. (2006). The dark side of diversification: The case of US financial holding companies. Journal of banking and finance, 30(8), 2131-2161. https://doi.org/10.1016/j.jbankfin.2005.04.030

60. Williams, B. (2014). Bank risk and national governance in Asia. Journal of Banking and Finance, 49, 10-26. https://doi.org/10.1016/j.jbankfin.2014.08.014

61. Williams, B. (2016). The impact of non-interest income on bank risk in Australia. Journal of Banking and Finance, 73, 16-37. https://doi. org/10.1016/j.jbankfin.2016.07.019

62. World Bank. (2016). South Asia Economic Focus, Spring 2016: Fading Tailwinds. Washington: World Bank. https://doi.org/10.1596/978-1-46480915-6

63. Yao, H., Haris, M., \& Tariq, G. (2018). Profitability determinants of financial institutions: evidence from banks in Pakistan. International Journal of Financial Studies, 6(2), 53. https://doi.org/10.3390/ijfs6020053 